\title{
Food utilization in the fish Tilapia mossambica fed on plant and animal foods
}

\author{
S. Mathavan, E. Vivekanandan \& T. J. Pandian \\ Zoology Department, Madurai University P. G. Centre, \\ Arulmigu Palaniandavar Arts College; \\ Palni, Tamilnadu, India
}

KURZFASSUNG: Die Nahrungsausnutzung des Fisches Tilapia mossambica bei pflanzlicher und tierischer Kost. Die Nahrungsausnutzung des herbivoren Fisches Tilapia mossambica wurde bei unterschiedlichem Futterangebot untersucht. Als Nahrung dienten die Grünalge Spirogyra maxima, Ziegenleber und lebende Kaulquappen. Mit Algennahrung allein konnten Jungfische ihren Energiebedarf nicht decken. Wurde darüber hinaus Ziegenleber verfüttert, so erhöhte sich sowohl die aufgenommene Nahrungsmenge als auch die Nahrungsausnutzung. Maximale Konversionsraten wurden bei ausschließlich tierischer Kost erzielt.

\section{INTRODUCTION}

Only a few publications are available concerning food utilization in herbivorous fishes (see Pandian, 1975). Menzel (1959) found that angelfish Holacantbus bermudensis, fed on epizoan-free filamentous algae, failed to deposit protein; he concluded that, though the utilized algae were sufficient to meet the metabolic energy requirements, the animal matter ingested intentionally or accidentally by the angelfish was essential to insure "true growth" (GERKING, 1952). However, the bluegill sunfish Lepomis macrochirus, fed on different combinations of the alga Chara sp. and animals, failed to yield evidence for more efficient utilization of Chara, and the bluegill fed ad libitum on Chara provided further evidence that the fish neither will nor can consume enough algae to meet its metabolic energy demands (KIrchell $\&$ WindeLL, 1970). The grasscarp Ctenopharyngodon idella showed absorption efficiencies of 20 or $40 \%$, when fed exclusively on the plant Lactuca sativa or Tubifex spp. (Fiscrer, 1972); these values are far lower than those usually reported for herbivorous (e. g. $H$. bermudensis: $72 \%$; MeNZEL, 1959) or carnivorous fishes (e. g. Opbiocephalus striatus: $83 \%$; Pandian \& Vivekanandan, 1975). When offered different combinations of these food organisms, C. idella fed a diminishing quantity of tubificids in the absence of $L$. sativa, and in the combinations providing less than $24 \%$ L. sativa (FISCHER, 1973). Thus, even the limited available information on food utilization in the herbiyorous fishes is contradictory, and calls for more comprehensive work. 


\section{MATERTAL AND METHODS}

Fingerlings of the herbivorous fish Tilapia mossambica $(1.5 \pm 0.25 \mathrm{~g})$ belonging to the same parents were acclimated in individual glass aquaria ( 11 capacity) to the respective food combinations for 10 days at $28^{\circ} \pm 1^{\circ} \mathrm{C}$. Spirogyra maxima, a natural food of $T$. mossambica (Chacko \& KrishnamurthI, 1954), was chosen as plant food; the goat-liver and frog's tadpole (mobile prey; size: $25 \mathrm{mg}$ ) served as animal foods. The algal filaments were washed carefully to remove associated animal matter. The individuals, which received different combinations of plant and animal foods (Table 1) were fed for $8 \mathrm{~h} /$ day, for a period of 15 to 20 days. Care was taken to collect unfed animal food remains with a pipette. Unfed plant remains were collected by filtering the entire aquarium with a fine sieve $(160 \mu \mathrm{m})$ every day after $8 \mathrm{~h}$ algal supply. Suitable corrections were made for the fluids lost from the liver pieces and the amount of plant material photosynthesised during the $8 \mathrm{~h}$ feeding period. The test individuals were observed frequently to remove the faecal segments intact with a pipette causing least disturbance. "Sacrifice method" (MAYNARd \& Loosl., 1962) was used for determining the water content of the test individuals. Absorption efficiency was estimated for each fish relating the quantity of total food absorbed (food consumed-faeces) to the quantity of total food consumed. Conversion efficiency $\left(\mathrm{K}_{2}\right)$ was estimated relating the growth of the fish to the quantity of total food absorbed (Pandian, 1967a).

\section{RESULTS AND DISCUSSION}

In the first series of experiments, different rations of Spirogyra maxima ranging from 4 to $40 \mathrm{mg}$ dry food/g, live fish/day were offered to Tilapia mossambica; the maximum amount of Spirogyra that the fish could consume in the given situation was $29.3 \mathrm{mg}-\mathrm{g}$-day (Table 1). Absorption efficiency increased with increasing rations of S. maxima from about $50 \%$ to $78 \%$; this may indicate that increasing the volume of ingested S. maxima stimulated increase in the rates of enzyme secretion and/or activity (see PANDiAn, 1975). as well as enhancing peristalsis (PANDIAN, 1967a), which augmented digestion rate. All groups fed on $S$. maxima lost different amounts of body substance ranging from 0.7 to $3.0 \mathrm{mg}$ dry body substance/g live fish/day; the group fed ad libitum $(40 \mathrm{mg} / \mathrm{g} /$ day) lost the minimum of $0.7 \mathrm{mg} / \mathrm{g} /$ day. The present observation supports the conclusions of MENZEL (1959) and KITCHELL \& WINDELL (1970) that to insure "true growth" in herbivorous fishes, animal matter is essential, and that a herbivorous fish neither will nor can consume and utilize sufficient amounts of algae to meet its metabolic energy demands. Different combinations of $S$. maxima with goat-liver in proportions ranging from 42 to $86 \%$ resulted in increased consumption (up to $38 \mathrm{mg} / \mathrm{g} /$ day), absorption efficiency $(94 \%$ ), and these, in turn, insured "true growth" rate of up to $9 \mathrm{mg} / \mathrm{g} /$ day. This supports the previous observation of KiTCHELL \& Windell (1970) that supplementing algae with animal matter increases feeding rate. The response of Ctenopharyngodon idella consuming a diminished quantity of tubificids in the absence of plant food (FISCHER, 1973) differs from the 
responses of Tilapia mossambica and Lepomis macrocbirus, which increased feeding rate with the increasing proportion of supplemented animal matter.

Supplementation of animal matter to Spirogyra maxima appears to produce a better "digestive climate", which resulted in decreasing the nondigestible, nonabsorbable fraction of S. maxima in Tilapia mossambica. For instance, in the combination, which was supplemented by $42 \%$ liver, the amounts of $S$. maxima and liver consumed were $10.0 \pm 1.16$ and $15.2 \pm 1.25 \mathrm{mg} / \mathrm{g} /$ day, respectively, and the amount of total faeces defecated was $2.2 \mathrm{mg} / \mathrm{g} /$ day; among the series feeding exclusively on $S$. maxima, the group receiving $14 \mathrm{mg} / \mathrm{g} /$ day absorbed the food with $62 \%$ efficiency, i. e. as much as $5.4 \mathrm{mg}$ of $S$. maxima was not digestible and absorbable, and hence defecated as faeces. Assuming all the $2.2 \mathrm{mg}$ of faeces defecated by the group receiving $58 \% \mathrm{~S}$. maxima $+42 \%$ liver was contributed by the non-digestible, non-absorbable fraction of $S$. maxima alone, this is less than half of what $(5.4 \mathrm{mg})$ was defecated as faeces by the group feeding $14 \mathrm{mg} S$. maxima g/day. Furthermore, the argument that the high absorption efficiency exhibited by the series receiving liver supplemented diet was partly or solely due to the fact that they consumed a larger volume of food, which augmented digestion rate, may not be applicable here. For the group which received only S. maxima and fed $29 \mathrm{mg} / \mathrm{g} / \mathrm{day}$, and the group feeding $28 \mathrm{mg}$ food supplemented with $68 \%$ liver-g-day displayed a statistically highly significant difference in its efficiency to absorb food $(t=10.870 ; \mathrm{P}<0.001)$; the former's efficiency was only $78.5 \%$ against the latter's $92 \%$. The fact that Lepomis macrochirus fed on Chara supplemented with animal matter failed to yield evidence for more efficient utilization of Chara sp. differs from that of Tilapia mossambica in which supplementation of $S$. maxima with animal matter resulted in better absorption efficiency.

The observation that the supplementation of animal matter increased the digestible fraction of Spirogyra maxima and hence absorption efficiency of Tilapia mossambica is interesting and unexpected. In this connection, the local action of secretagogues, i. e. partially digested animal matter, in modifying the "digestive climate" is important. It is not clear how such partially digested liver products could have modified the "digestive climate" favourably towards the reduction of the nondigestible, non-absorbable fraction of $S$. maxima in $T$. mossambica. This is currently being investigated.

The thind series, which fed exclusively on an animal diet consisting of liver pieces or live tadpoles of frog exhibited the highest feeding rates (over $41 \mathrm{mg} / \mathrm{g} / \mathrm{day}$ ), as well as the highest rate (over $10 \mathrm{mg} / \mathrm{g} /$ day) and efficiency (over $26 \%$ ) of food conversion. Both the groups showed about $94 \%$ absorption efficiency, which is comparable to that observed in the tarpon Megalops cyprinoides (Pandian, 1967b). Energy cost of predation on mobile prey organisms such as frog's tadpole appears to have decreased feeding rate from 47 to $41 \mathrm{mg} / \mathrm{g} /$ day and conversion efficiency from 30 to $26 \%$ in Tilapia mossambica receiving animal diet. 
Food utilization in Tilapia mossambica

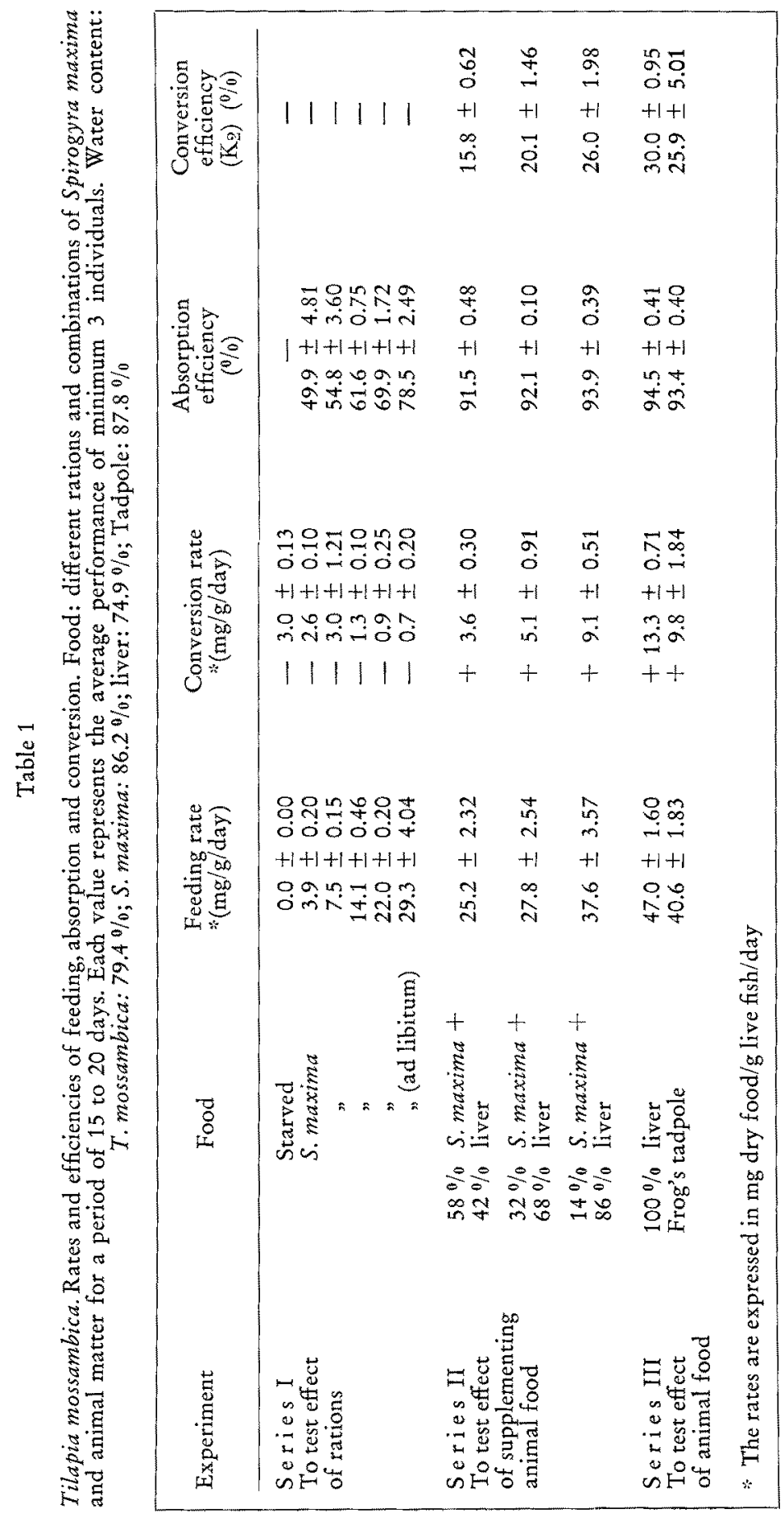




\section{SUMMARY}

1. When fed rations ranging from 4 to $29 \mathrm{mg}$ (dry) Spirogyra maxima/g live fish/day, absorption efficiency of Tilapia mossambica increased from 50 to $78 \%$; the young T. mossambica could not consume and utilize sufficient algae to meet its metabolic energy requirement.

2. On supplementing the algal food with goat liver, the fish consumed not only more food ( $38 \mathrm{mg} / \mathrm{g} /$ day) but also enhanced the absorption efficiency to $94 \%$.

3. Given only the liver pieces, the fish consumed $47 \mathrm{mg}$-g-day; it displayed 95 and $30 \%$ of absorption and conversion efficiencies. However, the fish preyed upon and could consume only $41 \mathrm{mg}$ tadpoles/g/day and convert with $26 \%\left(\mathrm{~K}_{2}\right)$ efficiency.

Acknowledgements. We are grateful to Prof. $O$. KInNe (Hamburg) for valuable suggestions and continued support, and to the C.S.I.R. (New Delhi) for financial support.

\section{LITERATURE CITED}

Chacko, P. I. \& Krushnamurthi, B., 1954. Observations on Tilapia mossambica Peters. J. Bombay nat. Hist. Soc. 52, 349-353.

Fischer, Z., 1972. The elements of energy balance in grasscarp (Ctenopharyngodon idella VAL.) II. Fish fed with animal food. Polskie Arch. Hydrobiol. 19, 65-82.

FischER, Z., 1973. The elements of energy balance in grasscarp (Ctenopbaryngodon idella VAL.) IV. Consumption rate of grasscarp fed on different types of food. Polskie Arch. Hydrobiol. 20, 309-318.

Gerking, S. D., 1952. The protein metabolism of sunfishes of different ages. Physiol. Zooll. 25, $358-372$.

KITCHELL, J. F. \& Windell, J. T., 1970. Nutritional value of algae to bluegill sunfish Lepomis macrochirus. Copeia, 1970, 186-190.

Maynard, A. L. \& Loosur, K. J., 1962. Animal nutrition. McGraw-Hill, New York, 533 pp.

MenzeL, D. W., 1959. Utilization of algae for growth by the angelfish, Holacanthus bermudensis. J. Cons. perm. int. Explor. Mer 24, 308-313.

Pandian, T. J., 1967a. Intake, digestion, absorption and conversion of food in fishes Megalops cyprinoides and Ophiocephalus striatus. Mar. Biol. 1, 16-32.

- 1967b. Transformation of food in the fish Megalops cyprinoides. Ir. Influence of quantity of food. Mar. Biol, 1, 107-109.

- 1975. Mechanisms of heterotrophy. In: Marine ecology. Ed. by O. KrnNE, Wiley-Interscience, London, 2 (1), 61-249.

- \& VIVEKANANDAN, E., 1975. Effect of feeding and starvation on growth and swimming activity in an obligatory air-breathing fish. Hydrobiologia. (In press.)

TrleR, A. V., 1970. Rates of gastric emptying in young cod. J. Fish. Res. Bd Can. 27, 1177-1189.

First author's address: S. MATHAVAN

Zoology Department

Madurai University P. G. Centre

Palni, Tamilnadu

India 